\title{
Media Art Futures
}

Sean Cubitt

\begin{abstract}
The artworks and debates surrounding the media art scene are used in this article as indicators of advanced research into the state of network communications and what they can tell us about the possible futures of both art and the globalisation process, insofar as both depend on the state of telecommunications. In particular, the article focuses on the claims of locative media art that small, mobile devices provide a utopian platform for social experiment. The theme of mobility is then investigated, distinguishing the freedom of capital to move from the stringent controls on human migration.
\end{abstract}

\section{The Political Economy of Networks}

Digital media artists have been struggling for a decade to find an adequate title for what they do. For some, the word 'art' is adequate: they are artists who happen to use digital tools, or that use a range of tools, traditional and contemporary. In many institutions the phrase 'new media art' has found a niche, but the recognition that artists have been working with digital devices since the 1960s makes the 'new' seem overstated, while failing to cover other emergent technologies that artists have begun to deploy, such as bio, genetic and nano technologies. The problem of naming the phenomenon has not however stopped a number of terms arising to describe specific forms of activity within the general realm of digital media arts. In what follows I look at the debates surrounding two of these, net.art and locative media. The discussion is framed by two more general arguments. The first places digital media art in the changing context of the network economy and the characteristic forms of network culture in the first years of the 21 st century, the era of what is now widely known as Web 2.0. The second discusses the critical place of code as both the enabling (and constraining) heart of digital media and a governing metaphor for the conduct of regulation and rule in digital culture. It is my contention that art practice acts not simply as a diagnostic device for the contemporary but as antennae sampling the likely directions of near and further future shifts in the social, cultural, economic and political formation of society. The sheer autonomy of the logic underlying digital technology, in both hard and software, gives it a peculiarly strategic position in sensing the future. The debates between net.art and locative media and related practices, I believe, are at heart about a key question for the future of global society: what real capabilities do people have to move from place to place? For net.art, the figure of the nomad derived from the anonymity and transparency of the internet. For locative media, it derives from the 
physical movement of crowds equipped with mobile phones. In this distinction, we can sense some of the choices facing humanity in the coming century.

In her keynote address to the 13th International Symposium of Electronic Art (ISEA), held in San Jose in August 2006, Saskia Sassen argued that the media arts community and the wider sphere of civil society activists stand to learn a great deal from the finance sector. Despite the (entirely predictable) sharp intakes of breath, Sassen's argument was convincing. The announcement that the New York Stock Exchange was pursuing takeovers of four European bourses (London, Paris, Amsterdam and Madrid) was, she opined, a matter not of purchasing the volume of trade, but the network capacities of the four stock exchanges. One thinks promptly of the BBC's inspired move into internet delivery in the 1990s, and into terrestrial digital broadcasting and global TV in the 2000s [I]: lessons learned from the spirit of venture capital, of early adoption of key emergent markets, and most of all of moves towards network media, where users can be relied upon to provide their own content. Rupert Murdoch's now well-known 2005 speech to the US Association of Newspaper Editors made a similar point [2]. Newspapers, he argued there, need to shift their centres of gravity from print to electronic formats, to be prepared to tailor themselves to individual consumer tastes, to employ bloggers as reporters and op-ed freelancers, and to reap the benefits of micro-targeted advertising technologies permitted by the world wide web.

From one perspective, these kinds of movement sound depressingly like the deskilling and casualisation that have plagued industry after industry in the period since the advent of computing [3]. But it can also be argued that the trade in goods of the industrial period becomes, in a postFordist era, a trade in customers. At first, a service-oriented economy is dependent on the loyalty of consumers, so much so that when brands change hands, it is the customer base which is the single most valuable property to be exchanged. But in an information economy, the consumer is no longer the endpoint in the cycle. Consumption of information goods like computers and mobile phones demands that we enter into the process as customisers of our devices, and as generators of content. The content of television is produced by professionals, but the content of telecommunications is produced by its users. The term 'prosumer' indicates on the one hand a new relationship of interactivity engaged quite consciously in sunrise industries. On the other, perhaps it still distinguishes too much between professional producers and unpaid consumers. The concept of unpaid creative labour in the information economy is one to which the contemporary and nearfuture media arts are increasingly paying attention $[4,5]$.

This trajectory has a history in art practice extending back to the historical avant gardes of the early twentieth century. The Constructivist reconstruction of the storming of the Winter Palace, 
filmed by Eisenstein for October, was staged as a public art event. Many parallel engagements with the public mark that heroic period of vanguardism, and reappear in what we might periodise as the beginnings of contemporary art, insofar as it is distinguishable from modern art, in the participatory works of Fluxus group artists like Yoko Ono, and perhaps most of all in hugely influential works like Joseph Beuys' I,000 Oaks, in which the art consisted inof volunteers planting a thousand saplings around Kassel. Happenings and performances gave way to interactive artworks among musicians like Cornelius Cardew, and perhaps most of all in the emergent new media forms of the last twenty years.

As artist and educator Miroslaw Rogala argues [6], this raises a kind of ethical and political question. To the extent that the artist passes on the job of completing the artwork to her audience, to exactly thate extent that the audience must take responsibility for its completion, or the art is simply incomplete. Such artforms, Rogala argues from his experience of leaving Stalinist Poland and migrating to the USA, offer an invitation to audiences to democracy, a democracy that likewise fails to the extent that it is consumed or toyed with rather than actively engaged in. The powerful allegoric aspect of Rogala's works derives from the strategic demand that he makes of his audiences: that they take ethical and aesthetic responsibility for the depth and richness of their own and others' experience of the art. Such works are truly experimental, in the sense that at every incarnation, they risk failure.

\section{net.art}

For others working in the interactive domain opened up, and in many respects democratised by the diminishing cost of digital and mobile technology, the new landscape is already overtaking what was only a few years ago the great new hope for a new medium: net.art. The name had a certain ring to it, celebrated in some recent publications like Rachel Greene's Thames and Hudson "World of Art" title, Internet Art [7] as a school, an informal international movement linking practitioners as diverse as Vuk Cosic, Alexei Shulgin, Graham Harwood and the group around Rhizome in New York. net.art (always lowercase and linked or divided, according to taste, by the network punctuator symbol of the full stop) was firstly native to the internet (mainly the world wide web but not exclusively). It presumed a degree of programming skill, and a readiness to abandon the usual formal constraints of proprietary software packages in order to create new avenues of possibility. At the same time, net.art abandoned the high-end glossiness of videographics in favour of a down and dirty satire on the underpinning codes of network communication. Cosic's ascii art used the ASCII (American Standard Code version 2) code set to convert images into arrays of symbols. Belgian-Dutch pair jodi produced apparently random screens of gibberish which, viewed as source 
code, revealed gigantic DNA spirals of programming. The Landfill project was one of dozens of alternative browsers that did anything but reproduce the laboriously normalised designs of webpages. Whole festivals were devoted to browsers, and to specific practices within them, like the Amsterdam festival of form art that played with the buttons and tick-boxes that spread over the net in the 1990s. While much net.art was highly formal, some, notably Olia Lialina's various projects and collaborations, were also capable of imaginative storytelling and emotional range, as in My Boyfriend Came Back From The War.

Already for many net.artists, the idea of interaction was becoming suspect. Young Hae Chung Heavy Industries, whose fragmented narratives programmed in Flash and accompanied by free jazz improvisation recordings, deliberately turned their back on interaction. Others followed suit, either abandoning interaction by programming in a sequence of changes, or by rendering interaction more or less pointless, as was the case with a number of jodi's Error 404 projects. The pioneering experiments of hypertext novelists like Stuart Moulthrop and multimedia poets like Mark America began to appear dated (though Morris and Swiss' collection on multimedia poets [8] demonstrates that the language arts are far from over in the digital arena). Nonetheless, it was clearly with the aim of shocking that Mark Tuters, artist and programmer on an autonomous robot surveillance and information blimp for ISEA 2006, told the Pacific Rim New Media Symposium that preceded ISEA that net.art was dead. Accusing net.artists of elitism, Tuters made a claim for the emergent field of locative art, such as his own, which opens up to interaction with local publics through ubiquitous consumer technologies like the mobile phone. Moreover, in a talk with eerie echoes or counterpoints with sassen's later keynote, Tuters argued that net.art had emasculated itself by refusing to work with commercial interests, preferring to see his practice as a kind of freelance Research and Development [9]. On the same panel Julian Bleeker, a hugely inventive and increasingly influential creator of lo-tech deliveries for hi-tech concepts, asserted, against a formative precept of net.art and indeed of much digital art, that he was in too much of a hurry to script new programmes, and was happy to hack existing technologies like Google Earth to realise his ideas. Like Tuters, Bleeker also was unembarrassed at involving commerce, though both found it ironic that the Minutemen, a self-organised volunteer militia patrolling the USA's border with Mexico to drive away potential migrants, are using exactly the kind of autonomous robot surveillance and information blimp that Tuters had designed for his locative art project in San Jose.

\section{Locative Media}

Locative art, which has already produced its first touchstone project in the form of Proboscis' Urban Tapestries, deploys mobile phones, geo-positioning systems (GPS), digital cameras, mp3 players 
and any other technologies it can lay its hands on to work in the opposite direction to the muchtouted dematerialisation of the internet. Locative media artists use a variety of game formats, mapping tactics and surveillance devices to create a sense of place by intermeshing the actual world with the digital that permeates it. The concept rests on ubiquitous computing: the increasing numbers of embedded or mobile digital devices that can connect a wandering audience with cellular networks, satellite or bluetooth internet, in order for example, in Urban Tapestries, to allow users to embed virtual memories and stories in actual places. As users move through the landscape of central London, they encounter hotspots where previous users have left images, tales and sounds, in what might be read as an effort to convert the impersonal placelessness of interchangeable urban landscapes with the construction of place through personal memories and shared experiences. That some of the projects are not wildly convincing doesn't matter, anymore than the fact that some paintings are worse than others would lead you to abandon painting.

As an immediate future mode of art, or at least an assemblage of media and a philosophy concerning the use of ubiquitous consumer technologies, locative art stands at one end of the multiple spectra of contemporary media art. In association with the ISEA exhibitions, the San Jose Museum of Art hosted a retrospective of Los Angeles digital artists Julia Steinkamp, Steinkamp was taught, among others, by the seminal theorist Gene Youngblood, whose Expanded Cinema [10] argued for a pure cinema of colour, movement and experience. Such is the basis for Steinkamp's huge wallfilling animated projections, the most successful of which use abstract geometrical forms, or in some extravagantly beautiful recent works animated flowers not entirely without reminiscences of William Morris wallpaper, hanging garlands blowing in invisible winds. Steinkamp's works are in some sense purely spectacle. They might be said in some way to be 'about' space or duration, but what one takes away from them is their loveliness, the brilliance of their colours, the satisfying grace of their movements. Spectacle is the ordinary bedfellow of the digital arts, which are capable of so much, especially in the thoroughly digitised print media, and through the advance of data projection, notably Texas Instruments' patented DLP (digital light programming ) system, towards big, bright screens visible in daylight.

Locative media are far less intrusive, indeed without the right kinds of portable equipment, there is often very little to let you know that you are in the area of an art work. The denial of spectacle has become a regular trope in contemporary digital media arts. Exhibiting in the Sydney Biennial 2006, Rafael Lozano-Hemmer installed three plasma screens showing greyscale images of the gallery floor from CCTV cameras, with, faintly marked below them, an array of short lines that moved about in some apparently random order. The screens themselves proving rather uninter- 
esting, the majority of passers-by failed to notice that the lines represented an array of a hundred or so motorised fluorescent tubes in the ceiling, thatceiling that realigned themselves according to patterns of movement through the gallery. Like a language that we have forgotten we speak, lighting is no longer an object to look at. Its invisibility is proof that it has become second nature. The same must be said now for closed-circuit television: we are inured to the fact that we are constantly on screen somewhere. These invisibilities become the subject of an artwork that, once noticed, becomes spectacular. It also permits a meditation on the reality of spectacle: that it is we ourselves who have become images, and after images, code. It is the spectacle of our own vanishing. At the same time, like surveillance technologies generally, the hidden cameras assure us that we are both occupying very definite space and time coordinates, and simultaneously inhabiting a wholly neutral space, a space that might be anywhere whatever. The gap between the pinpointing of existence in a specific time and place and the vanishing of that place and its inhabitants into dataspace is whisper-thin.

This perhaps is what is missing from the advocacy for locative media. An attempt to reclaim the city, especially, as a real place, a place of memories and habits, of stories and dreams, of traditions and recurrences, a place in which events can once again occur, is hard put to distinguish itself from the spectacularisation of cities, the globalising tendency not just to make all cities the same as one another (the same shops, the same hotels, the same cuisine) but also the commercial imperative to give each city its landmark architecture, its signature restaurant, its irreplaceable cultural institution. Lozano-Hemmer, unlike Tuters, is resigned to the disappearance of identity.

During the 1960s, the rise of performance and concept as media for art came largely as a response to the recognition that any artwork was doomed to enter the cycle of capitalism, and to become a commodity. Much of the work of the conceptualists and performance artists was designed to escape that fate. Ironically, when that generation came to retire, unlike the painters, they did not have a studio full of works to see them through their twilight years. Neo-conceptualism has made its peace with the commodity form, taking its cue from Warhol. That neo-conceptual art, like the controversial Young British Artists' Sensation show at the Royal Academy, has become a spectacle is ironic to the extent that the commodity relation - where the relationship between people takes on the fantastic guise of a relationship between things - had itself become a relation between images already in the 1960s. Forty years later, the commodity takes on the equally fantastic but now scarcely humanly imaginable form of that relationship between data sets which computer scientists call code. 
Launched at an invitation event in August 2006, Jeffrey Shaw and his collaborators demonstrated iCinema, a project which uses a 360-degree surround screen about 3 metres high and perhaps ten metres in diameter with 24 or more channels of sound, stereoscopic and 360-degree cameras, interactive technologies and tracking engines to produce, again, spectacular but in this case much more immersive experiences for viewers. One fascinating experiment is composed of still 3D images, visible through polarised eyeglasses, intensely bright, and of remarkable resolution. Designed to be seen from a central viewing point, the works exhibit strong parallax effects when you attempt to move through the area within the screen. Every sway as you walk, usually automatically corrected by the brain, registers as a perspective shift in this unfamiliar environment. A populated village square in India, frozen arbitrarily in time by the huge 3D photograph, is no longer itself but like some strange special effect from a time-travel film. These shots, made in collaboration with an archeological and heritage project, and carefully articulated with religious, ethical and technical expressions from the location, make clear another failing of the locative thesis. Spaces may perhaps be mapped onto one another: they cannot be mapped onto themselves. Shaw's iCinema is intensely aware of its dislocation, and in many respects the existing projects are indeed not about location but specifically about dislocation, not least the dislocation through which mythic experience can enter the mundane world. Most existing locative media have yet to realise that the disjuncture between times and spaces, the failure of places to be identical with themselves, is not curable.

Strange, again, since to some extent one can read in locative media a memory of Guy Debord's practice of the dérive, the random stroll through a city that would reveal its psychogeography, the secret rifts, class division, racisms, interpenetrations of capital and working class culture, surreal juxtapositions and modernist brutality. Strange to the extent that Debord originated the phrase 'society of the spectacle' [I I] in a flurry of intense Hegelian Marxist analysis of the commodity form and its developments in post-war Europe. The Urban Tapestries project is unique in its focus on creating, maintaining and developing a platform for 'an anthropology of ourselves' sufficiently open-ended to enable not only the production of identities for users and the places they live but, very significantly for the future of the media arts, the possibility of producing non-identity.

The next phase of iCinema research involves an engine which will search metadata tags attached to audiovisual materials, typically short scenes, and assemble them according to search criteria entered by users in a search engine. This ambitious project chimes with a far more modest but artistically fascinating work by New Zealand artist Douglas Bagnall, Filmmaking Robot, exhibited at ISEA. The robot roams the streets of San Jose for the duration of the festival aboard a tram on the local light railway, shooting footage as it goes, and uploading to a server. At night, when there is not 
enough light and the trams don't run, it edits the resulting footage, responding to viewers' expressed preferences to develop rules of editing. These robotic associations reveal an inhuman understanding of a very human activity, commuting. Without in any way implying that commuting is in any sense robotic, the choice of subject matter seems appropriate: that aboard public transport, we are no longer ourselves but passengers, and we move according to the guidance given us by the design of the transport. Our typical or habitual actions betray our belief in ourselves as willing, self-orienting, desiring, evenand even communicative animals. Machine-driven montage, for example poetry engines by John Cayly and Simon Biggs, reveal likewise the automatism of the everyday, in the sense of a practice, like language, that has become so deeply embedded that we no longer recognise its presence. This, Bagnall's robot seems to say, is a matter of code.

\section{Code}

Code has become the key metaphor in electronic arts, for example as the title of the 2003 Ars Electronica exposition. Locative media is an attempt to escape this stranglehold. It is an attempt which echoes the anti-gaming games produced by jodi and others, for example Cory Arcangel's Super Mario Clouds, which strips the old Nintendo game of everything except the scrolling 8-bit skyscape, an endlessly looping refusal of interaction. Intervening at the level of code to critique code's ubiquitous invisibility is answered, in locative media, by the attempt to reveal the material realities which code elides, both human and physical. Any thinking about the future of media arts must begin with this debate: what is the ontology of an increasingly digital world? What is the ontology of ubiquitous and embedded computing, of wearable computers like the increasingly sophisticated mobile phone? Anti-interactive art surely expresses the limitations to interaction delivered by commercial interactive packages such as games, where choice is limited by the rules of the game, and is in any case restricted to the screen and its audio channels. At the same time, however, the attempt to rescue from the digital an older experience of the city, and in particular to attempt to resurrect the physical world from its ruins, smacks of nostalgia.

Like landscape art, as it moved from the formal gardens of Versailles to the 'republican' gardens of the English tradition [12], locative media, and in some sense Jeffrey Shaw's stereoscopic landscapes, struggle to recreate a lost natural order of perception, but instead reveal an emergent politics of location and habitation. Becoming spectacle is the fate of the world and its observers, becoming code the next stage in the same trajectory. For Futures, the question must be, where does this trajectory lead, and what alternatives might become possible? 
Speaking at ISEA, Raqs Media Collective addressed the Pacific Rim New Media Symposium through a series of fictional scenarios of the Pacific: cargo cults, Easter Island's ecological collapse, Lemuria. For them, the Pacific is a fiction to the extent that it takes a series of actual things and practices navigations, wildlife, detention centres - and constructs from them an idealised identity, the absurd concept of the identity of an ocean. In their exhibition in the Sydney Biennial, The Impostor in the Waiting Room, they produce, through video and installation, a profound impression that every waiting room produces performances, acts, impostures, and that the achievement of the 20th century has been construct, institutionally and architecturally, a planet of waiting rooms in which we all are condemned to act out part after part in the attempt to cross whatever threshold the room constructs, in order to reach a hoped for place where genuine actions take place.

If the conceptual and performance art of the 1960s attacked the commodity, it did so from the perspective of consumption. The consumer was the central figure, and disrupting the moment of consumption the goal. In the early years of the 2 Ist century, the consumer is no longer a passive recipient but the actor whose work completes the cycle of production. Economists have coined the term 'prosumer' to define this characteristic actor, who completes the design of her car by selecting from the options; completes the production of her kitchen by measuring up, ordering for just-in-time manufacture, and taking the flat-packed results home to install herself; who books her own flights online instead of buying from a travel agent; who installs her own software to make her computer work. The prosumer is the characteristic form of the game player, the web-surfer, the e-mailer. The prosumer creates the content of telecommunications networks. And it is the prosumer who is the target of locative media artists, for whom the production of something real undercuts the immateriality not only of net.art but of the whole digital culture. In both instances, the opposite of the consumer-prosumer is the citizen: the active, engaged, responsible agent of history. Such art is in this respect nostalgic: it harkens back to an imaginary era of republican or revolutionary virtue, when everyone knew that everything was political. What Raqs Media Collective propose is that a new constellation is emerging, beyond the citizen-consumer dialectic, and that it is not past but future, and that its name is the migrant.

\section{Migration and Mobility}

For much of the new media community, the terms nomadic or migrant, used interchangeably, are positive. True, locative media argues for a sense of place, but it does so from the standpoint of the indigene, or, since not actually the position of first peoples, of the settled (and the settler). At ISEA, and again at the Sydney Biennial, Maori artist Rachel Rakena invited a more contestatory sense of indigeneity, evoking in San Jose the diaspora of Maori, and their relinking through e-mail, 
and in Sydney the echoes of the ancient navigations in the present-day, too often unwelcomedunwelcome migrations of Polynesian islanders. Migration is rarely simply a good, or simply an evil. Migrants are as often pulled by attractions towards a good life as they are pushed by privation, war and oppression, and for most the choice to move, and of where to move, is the result of complex mixtures of leaving and arriving, belonging, not-belonging and belonging differently. The time, or more technically the temporalities of migration, and the places, or the localities, are complex, interleaved with regret and hope, places constructed as times, and times, like the time of the waiting room, constructed as places. Here digital media are both links with home and weavings into new diasporic and host communities, but also policing systems, and often the two are hard to distinguish. Of all the practices the world has to offer, migration is the one that reveals most clearly the class structure that still persists across the planet. For the wealthy cosmopolitan, boundaries are almost always transparent. For the poor immigrant, they are almost always opaque.

The new media arts are uniquely placed to make apparent, to question, to celebrate, to rebuild the conditions of migration that emerge now as the most significant aspects of the 2 Ist century's human life, a life where even the decision to stay at home is a refusal to migrate. There is a sense in which, in the post-spectacular regime of code, identity is no longer cultural, no longer anchored to a place and to common memories of shared actions. As Karl Krauss once observed, events no longer occur: the clichés operate spontaneously. For us it is not even clichés but code that occurs, as statistical aggregate and actuarial probability. The welfare states of the post-war settlement collapsed under the pressure of resurgent capital, East and West, but left as their legacy the resolution of the old dichotomy between citizen and subject in the form of the client. The political entity that acts today is the client, not as actor or victim but as statistic: as a figure in an opinion poll. The subject might be urged to drive carefully; the citizen might be persuaded; but the client is asked whether they recall the message in the safer driving adverts, and success of the campaign is measured by the number of deaths from speed and drunken driving.

The client emerges from the collapsed dialectic of citizen and subject just as the prosumer emerges in the post-Fordist collapse of the consumer-producer opposition, the former as the avatar of the new service sector, the latter of post-Fordist production. If this analogy were to hold good, then the migrant would resolve the dialectic of neighbours and strangers as the figure of finance capital, and that indeed is the case with the cosmopolitan, everywhere at home, always ready to leave. Yet it is clear that the realities of migration for the poor everywhere butt up against the all too material reality of borders, economic exclusion and the politics of culture that has replaced and revivified racism [13]. At this juncture the identity politics and cultural identities 
that seemed so liberating in the last years of the 20th century appear as inchoate but solidifying prison bars in the early 2 Ist. Nor is it humans alone who suffer these indignities: financial data has the freedom to migrate; but news, fictions, arts do not. Information wants to be free, but as the cyberpunk slogan has it, but is everywhere in chains. If art is the pursuit of freedom, expression of utopian yearnings without definite content, then art's most pressing task in the coming decades will be to lead the struggle for the right to move. At the same time, however, if art is to be able to recognise the full import of the freedom to migrate, then it must also face up to the imperatives of indigeniety. Places remain, cultures persist, tradition, which modernity was supposed to have annihilated, is reviving and ready to fight for its right to continue. The struggle between Indian settlers and 'ethnofascist' Fijian islanders under George Speight's leadership is a small indicator of a widespread,widespread and perhaps global dialectic between the right to belong and the right to move and to remove. If it is the case that we have only the rights we fight for, then the battle between conflicting rights is likely to be bloody. It is precisely at such points that art undertakes its most vital and utopian tasks, creating the forms in which the battle can take place without bloodshed. In response to Sassen's arguments to ISEA, art may respond, in that mix of code and materiality which begins with locative media but which must urgently overcome the localism it expresses, that what we most stand to learn from finance capital is speed and ephemerality, to belong everywhere and nowhere.

\section{References}

[I] G. Born Uncertain Vision: Birt, Dyke and the Reinvention of the BB., Vintage, London 2005.

[2] R. Murdoch, Speech by Rupert Murdoch to the American Society of Newspaper Editors, April 13, http://www.newscorp.com/news/news_247.html, retrieved April I4 2005.

[3] H. Braverman, Labour and Monopoly Capital: The Degradation of Work in the Twentieth Century, Monthly Review Press, New York, 1974.

[4] D. Butt, Class in the Information Society: Socio-economic reproduction in the new media environment, MA thesis, MacQuarrie Univesity, Sydney; http://www.dannybutt.net, 2004

[5] N. Dyer-Witheford, Cyber-Marx: Cycles and Circuits of Struggle, University of Illinois Press, Urbana, 1999. 
[6] R.W. Kluszczynski (Ed), Miroslaw Rogala: Gesty Wolnoski/Gestures of Freedom:

Prace/Works 1975-2000, Centrum Sztuki Wspólczesnej - Zomek Ujoazdowski, Warszawa, 200 I.

[7] R. Greene, Internet Art, Thames and Hudson, New York, 2004.

[8] A. Morris and T. Swiss (Eds), New Media Poetics: Contexts, Technotexts and Theories, MIT Press, Cambridge MA, 2006.

[9] M. Tuters, and K. Varnelis, 'Beyond Locative Media', Networked Publics, Annenberg Centre for Communication, Unversity of Southern California, January 19, 2006 http://netpublics.annenberg.edu/, retrieved 27 August 2006.

[10] G. Youngblood, Expanded Cinema, Studio Vista, London, 1970.

[II] G. Debord, The Society of the Spectacle, revised translation, no translator credit, Black \& Red, Detroit 1977 [1967].

[12] M. Warnke, Political Landscape: The Art History of Nature, trans David McClintock, Reaktion Books, London, 1994.

[13] E. Balibar, 'Is There a "Neo-Racism"' in E. Balibar and I. Wallerstein, Race, Nation, Class: Ambiguous Identities, (trans of Etienne Balibar by Chris Turner), Verso, London 199I, 17-28.

Notes on Contributors

Sean Cubitt (scubitt@unimelb.edu.au) is Professor and Director of the Program in Media and Communications, University of Melbourne. His recent publications include The Cinema Effect, EcoMedia and, as co-editor, Against The Grain: The Third Text Reader. 


\section{University Library}

\section{- M M N E R VA A gateway to Melbourne's research publications}

Minerva Access is the Institutional Repository of The University of Melbourne

Author/s:

CUBITT, S

Title:

Media Art Futures

Date:

2007

Citation:

CUBITT, S. (2007). Media Art Futures. Futures, 39 (10), pp.1149-1158. https:// doi.org/10.1016/j.futures.2007.05.001.

Publication Status:

Published

Persistent Link:

http://hdl.handle.net/11343/34716 